\title{
Cidade Universitária da Universidade do Brasil
}

Os únicos conjuntos destinados ao ensino superior em efetiva construção no pais, sob a responsabilidade do Govêrno Federal, correspondem às Cidades Universitárias da Universidade do Brasil e da Universidade do Recife. A de São Paulo está a cargo do próprio Estado e as outras, já federalizadas, executam apenas obras de reforma e ampliação ou constroem edifícios isolados

A futura Cidade Universitária da capital da República, projetada para 30.000 estudantes, constituirá um conjunto arquitetônico de grandes proporções, mas isento de suntuosidade.

A sua construção, como todos os empreendimentos dêsse tipo, exigirá, indubitàvelmente, a aplicação de recursos vultosos. As modernas universidades são, com efeito, integradas por numerosos e complexos laboratórios de ensino $e$ pesquisá, além de custosas instalações hospitalares. Por isso mesmo o padrão de tais obras deve garantir solidez e durabilidade superiores às comuns.

A execução dêsses conjuntos procedeu-se, no passado e ainda hoje em muitos casos, de modo lento e progressivo, acompanhando o crescimento das universidades a que se destinavam e o desdobramento de seus currículos. Em nossos tempos, porém, são cada vez mais freqüentes as cidades universitárias rápida e totalmente construídas, como ocorreu. a de Roma, Atenas, Caracas, Miami e, principalmente, com o majestoso "campus" recém-inaugurado da Universidade do México, erguido em menos de cinco anos.

A grande extensão dos terrenos da Ilha Universitária, que medem cêrca de 600 hectares, e ainda a multiplicidade 
dos edificios a construir, a par das numerosas obras de urbanização a serem executadas, permitiriam, sem dificuldades, alcancar-se, no Brasil, êxito análogo ao verificado nos países citados.

Não fôssem as dificuldades financeiras que a nação vem enfrentando há vários anos, ter-se-ia podido acelerar de muito o rítmo relativamente lento daquelas obras. Consciente dessas restrições, conduziu o Govêrno o planejamento da Cidade Universitária da Universidade do Brasil de modo a permitir a conclusão e o imediato funcionamento de cada unidade escolar, independentemente da terminação geral de todo o conjunto.

Para tanto, foram atacadas as obras fundamentais de formação da Ilha Universitária, mediante os aterros de unificação e saneamento do primitivo arquipélago, bem como iniciada a construção de apenas quatro edificios destinados, respectivamente, ao Hospital de Clínicas, à Escola Nacional de Engenharia, à Faculdade Nacional de Arquitetura e ao Instituto de Puericultura, êste já concluído e em funcionamento há cêrca de dois anos.

Por deficiência dos recursos orçamentários, numerosos trabalhos têm sido adiados, inclusive relativos a projetos já aprovados pelo Exmo. Sr. Presidente da República.

Penoso é verificar que o inevitável retardamento das obras de construção de nossa principal Cidade Universitária recuará, ainda mais, o dia em que poderemos ver os nossos indices de ensino erguidos acima dos baixos níveis em que jazem presentemente.

Todos sentimos a importância e a necessidade de se ampliarem os nossos recursos destinados à formação de técnicos, cientistas e de profissionais de nível superior. O indice percentual dêsses elementos humanos em relação ḋ população ativa do país é de apenas 0,50 ao passo que nos Estados Unidos da América do Norte êle atinge a 6,8, tendo sido de 1,3 em 1840. 
O número de estudantes de nível superior na Argentina, em 1950, atingia a 79.000, ao passo que no Brasil oscilava em tôrno de 40.000 e ascendia a 2.173.000 na grande república do norte.

Segundo o Anuário Estatístico de 1954, o número de alunos matriculados em todos os nossos estabelecimentos de ensino superior, federais, estaduais, municipais e particulares, ascendeu a 64.600. Nesse cômputo incluem-se, também, os estudantes de biblioteconomia, enfermagem, jornalismo, policia civil, servicos sociais, etc.

Os universitários, no Distrito Federal, atingiam a 15.200; em São Paulo a 15.95\%; em Minas Gerais a 5.934; 5.068 no Rio Grande do Sul e 4.180 em Pernambuco.

As matrículas, nesse ano de 1954, na Universidade do Brasil, somaram 7.345, enquanto que na de São Paulo êsse número foi de $6.806 ; 2.714$ na de Minas Gerais e 3.012 na do Recife.

Na base dêstes dados, o indice da população estudantil de nível superior foi, em 1954, de 1,13 por mil habitantes. Esse mesmo indice, no Distrito Federal, subiu a 5,6; a 1,6 em todo Estado de São Paulo; 1,3 no Estado do Rio Grande do Sul; 0,74 no Estado Minas Gerais e 0,81 em Pernambuco.

E' curioso observar que enquanto o Govêrno Federal mantinha 204 unidades escolares com 26.862 estudantes, as entidades particulares dispunham de 306 unidades com 26.900. Os governos estaduais e municipais custearam, nesse ano, apenas 88 escolas superiores com $10.878 \mathrm{ma}$ trículas.

Em 1952, para 56.045 estudantes universitários, existia um corpo docente de 9.486 professôres, isto é 5,9 alunos por professor, indice relativamente bom, caso não fôsse o professorado, em grande parte, mera atividade supletiva.

Mesmo que o nosso índice universitário suba, até o fim do século, modestamente, a 2 por mil habitantes e a nossa população alcance, apenas, a casa dos 90 milhões, o número de matriculas nas escolas superiores atingirá a 180.000 . 
Éstes dados mostram que, depois de concluídas tôdas as Cidades Universitárias atualmente em execução, inclusive as obras de reforma e ampliação dos velhos prédios existentes, ainda terá o país de construir, em 40 anos, outros centros de ensino superior para atender a um mínimo de mais de 120.000 estudantes, além dos $60.000 \mathrm{com}$ que contávamos em 1954.

$\mathrm{Na}$ verdade, carece de orientação precisa a fixação de vencimentos para o funcionalismo, tanto do Executivo, como do Legislativo e do Judiciário. O que se verifica é a heterogeneidade de critérios na remuneração de funcionários incumbidos de idêntìcos serviços nos quadros de cada um daquêles poderes: carreiras e cargos da mesma denominação $c$ equivalência, escalonados em padrões de vencimentos os mais diversos; funcionários que executam trabalhos da mesma categoria, pagos em bases desiguais.

(Trecho do relatório da Comissão de Classificação de cargos, 1954). 